\title{
Editorials
}

\section{Helping the Needy}

This journal is international, which means that it reaches an international audience with articles from international authors. What does this mean for international authors?

We actually accept about one third of submitted papers. This is obviously modest compared to the figures for The Lancet and the New England Journal of Medicine, where about 1 in 10 is accepted. It means that we have some leverage and are not in an impoverished situation where we have to accept every manuscript. This may well be true of other journals. Given that there are many geriatric psychiatry journals (see article by Holt et al., Vol. 9, No. 4, 1997, pp. 373380 ), how well do they survive the competition? Are there any market trends in this modest market?

Without it sounding like humbug, International Psychogeriatrics does worry about its constituency. Are we giving our readers the best possible articles? Are we giving our authors good return? What happens in effect is that we submit all manuscripts to critical and impartial review. This means that every manuscript goes to the best scientists in our field. One of the most involved tasks for an editor-in-chief is to solicit and gain the help of a colleague who will give sound critical advice without personal benefit. Being an examiner, sitting on grant committees, and reviewing manuscripts are among the hardest and most invidious tasks that academics and healthcare professionals undertake. It is hard at times to be fair and objective. Nevertheless, our reviewers are generally outstanding and give consummate critical advice. Unless they reject the paper out of hand, which isn't that often, the choices are "major revision," "minor revision," or "accept." We generally give liberal interpretations, which means the least will be lesser and the lesser forgivable. This is done in the spirit of fairness so that the efforts of our authors are maximized. We are well aware that not all of our authors have access to the best statisticians, methodologists, and writers of English. All of this is well and good and we're happy to ensure that the best of our authors become even better. In effect then, the reviewers upgrade the quality of the papers.

However, couldn't this be wrong? Are we turning too many sow's ears into silk purses? There can be little doubt that the quality of the accepted papers is enhanced by virtue of being reviewed. This in turn exalts the journal. So what does it matter? The major scientific journals like The Lancet accept fewer articles and, even then, rewrite them. This means that published papers look as though they are written by perfect penmen. This usually does not worry the authors because they are simply happy to have a paper accepted 
in The Lancet. This may well be true of our authors. We do not generally rewrite, but do request substantial revisions at times.

So our gallant band of unpaid, unsung reviewers continues to enhance the journal with skilled reviews of submitted materials. We acknowledge the reviewers of course at year end, but suffice it to say that our journal is so much the better for their help. Scientific medicine is dependent upon such giving people and many of them are unstintingly helpful. We very much admire them.

\author{
Robin Eastwood, MD \\ Editor-in-Chief \\ St. Louis, MO, USA
}

\section{Letters, Belles-Lettres, and Silence}

When the Titanic sped towards New York, the captain was less concerned about icebergs than about transatlantic records. Nevertheless when the ship crashed, the captain did his duty and went down with the ship. Captains lead lonely, but not necessarily isolated, lives. What about editors? I do not wish to drown, but do lament the lack of letters (or correspondence as it is called elsewhere in the English-speaking world). Despite the pleas, nobody answers the call for letters to the editor. Like the captain, I want to know what's going on and what people think.

When I grew up in England, writing to newspapers was an art form and a democratic right. People would compete to be the first person to hear the first cuckoo of the year. Vicars, squires, and colonels would sweetly or crankily air their views about the state of the universe in no uncertain terms. Are there no International Psychogeriatric Association members and readers fit to bust to express themselves in print? Can I not cajole members into giving their opinions of articles or other points of view? Letters, even belles-lettres, will be welcome, but definitely not silence.

Robin Eastwood, MD
Editor-in-Chief
St. Louis, MO, USA 